\title{
Implementasi One Time Password Menggunakan Algoritma SHA-512 Pada Aplikasi Penagihan Hutang PT. XHT
}

\author{
Rizki $^{1}$, Sri Mulyati ${ }^{2}$ \\ ${ }^{1,2}$ Program Studi Teknologi Informasi, Universitas Budi Luhur \\ email: 1611510296@student.budiluhur.ac.id ${ }^{1}$, sri.mulyati@budiluhur.ac.id ${ }^{2}$
}

(Received: 28 Mei 2020/Accepted: 8 Juni 2020 / Published Online: 20 Juni 2020)

\begin{abstract}
Abstrak
PT. XHT adalah salah satu perusahaan swasta bergerak di bidang penagihan hutang. Perusahaan ini memiliki sistem penagihan hutang berbasis web. Namun, pernah terjadi pencurian username dan password pada sistem berjalan. Hal ini disebabkan banyak hal, diantaranya password yang terlalu mudah. Salah satu solusi mengatasi hal ini adalah dengan meningkatkan keamanan autentikasi, yaitu dibuat sistem One Time Password. Pada penelitian ini dibuat sistem keamanan login One Time Password menggunakan fungsi hash SHA-512. Dalam mengembangkan sistem ini menggunakan metode Waterfall Development sebagai siklus hidup pengembangan perangkat lunak. One Time Password sebuah kode acak hanya dapat digunakan satu kali. Pengujian melibatkan beberapa pihak, diantaranya Ahli Media dan Ahli Materi, serta menggunakan metode black box. Hasil uji black box menunjukkan kelayakan fungsi button berupa masukan dan keluaran. Sementara itu, hasil uji oleh Ahli Media mendapat nilai 82\%, sedangkan Ahli Materi adalah 75\%. Sehigga dapat disimpulkan bahwa sistem login One Time Password menggunakan SHA-512 layak digunakan untuk keamanan pengguna.
\end{abstract}

Kata kunci: Algoritma SHA-512, Aplikasi Penagihan Hutang, One Time Password, Waterfall

\begin{abstract}
PT. XHT is a private company engaged in debt collection. This company has a web-based debt collection system. However, there has been a theft of usernames and passwords on the running system. This is due to many things, including passwords that are too easy. One solution to overcome this is to increase authentication security, which is a One-Time Password system. In this research, login security system is created using the SHA-512 hash function. In build this system using the Waterfall method as the life cycle of software development (SDLC). This system is a random code can only be used once. The test involved several parties, including Media Expert and Material Expert, and using the black box method. Black box test results indicate the feasibility of the function from the input and output buttons. Meanwhile, the results from the test by the Media Expert scored $82 \%$, while the Material Expert was 75\%. So it can be concluded that the One-Time Password login system using SHA-512 is suitable for user security.
\end{abstract}

Keywords: Algoritma SHA-512, Debt Billing Application, One Time Password, Waterfall

\section{PENDAHULUAN}

Pada era globalisasi seperti saat ini, kehadiran teknologi informasi sangat berperan penting dalam perubahan di dunia. Perkembangan ini juga mempengaruhi di berbagai bidang, seperti; pertanian, perindustrian, pemerintahan, kesehatan, dan pendidikan. Manusia sebagai pengguna teknologi harus mampu memanfaatkan teknologi informasi yang ada saat ini, maupun perkembangan teknologi informasi tersebut selanjutnya. Tanpa di sadari, penggunaan teknologi informasi telah banyak membantu manusia untuk menyelesaikan pekerjaannya. Oleh karena itu, penggunaan teknologi informasi tersebut baru dapat dirasakan 
manfaatnya jika diberikan kepada orang yang tepat, sehingga informasi juga harus relevan terhadap penggunanya (Kinarwanto, 2016).

PT. XHT adalah salah satu perusahaan swasta yang memanfaatkan teknologi informasi bergerak dibidang penagihan hutang. Penagihan hutang di perusahaan ini menggunakan aplikasi berbasis web yang dilakukan oleh seorang user. Sebelum masuk ke dalam sistem, user di haruskan melakukan login terlebih dahulu dengan memasukkan username dan password (Khairina, 2011). Setelah berhasil, barulah user bisa melakukan penagih hutang kepada pihak client yang memiliki tagihan. Permasalahan mulai muncul saat salah satu user tidak hadir atau tidak bisa melakukan penagihan. User lain tentu sangat mudah melakukan login dengan menggunakan username dan password user tersebut. Hal ini di akibatkan karena keamanan account sesama user yang sangat rentan dan kurangnya ke waspadaan user dalam menggunakan username dan password. Selain itu user lain yang berhasil login dan bukan menggunakan account nya, dapat melihat dan mengakses seluruh data client tersebut.

Berdasarkan paparan masalah tersebut, maka perlu di kembangkan keamanan sistem login yang dapat mengamankan account user. Ada beberapa ide pengembangan yang dilakukan, salah satunya token. Password pelapis kedua ini lebih banyak di kenal dengan One Time Password (OTP). Setelah sebuah password dipakai, maka password yang sama tidak dapat dipakai untuk kedua kalinya. Password tersebut sebuah kode acak yang selalu berubah dan hanya bisa dipakai satu kali. Kode acak di dapat dengan menggunakan algoritme SHA - 512 sebagai pembangkit kode OTP . Pembangkit kode OTP berjalan setelah user memasukkan username, password dan waktu saat melakukan login. Pegiriman kode OTP ada yang melalui SMS, Email atau aplikasi android.

Algoritme SHA-512 termasuk jenis fungsi hash yang merupakan pengembangan dari algoritme SHA-1. Fungsi hash adalah fungsi yang menerima masukan string yang panjangnya sembarang dan mengkonversinya menjadi string keluaran yang panjangnya tetap (fixed) (Adilah et al., 2017; Sakti et al., 2016). Algoritma SHA - 512 panjang nilai hash yang dihasilkan adalah 512 bit sebagai fungsi hash mempunyai sifat-sifat seperti : 1) Sifat requirement, $\mathrm{h}$ mudah dihitung bila diberikan $\mathrm{M}$. Jika $\mathrm{h}$ sukar dihitung, maka tidak dapat menggunakan fungsi hash. 2) Sifat oneway function, mudah menghitung $\mathrm{h}$ dan sukar mengembalikan nilai M. Tanpa sifat tersebut mudah menemukan nilai keduanya. 3) Sifat collision free, mencegah kemungkinan pemalsuan. Tidak mungkin mencari $\mathrm{M}$ dan $\mathrm{M}$ ' sehingga $\mathrm{H}(\mathrm{M})=\mathrm{H}\left(\mathrm{M}^{\prime}\right)$ (Mulya, 2009; Sugiyatno \& Atika, 2018). algoritma SHA - 512 sebagai pembangkit kode OTP untuk keamanan sistem login. Kode OTP ini oleh sistem akan di kirimkan ke user melalui SMS yang berguna untuk meng - otentikasi apakah user yang melakukan login benar - benar dirinya (Kurniawan \& Fatimah, 2018; Naufal \& Purwanto, 2018; Yahya \& Amini, 2018). Otentikasi ini akan dicocokkan dengan yang ada pada sistem (Al Azam, 2016). Namun SMS memiliki delay atau jeda waktu yang lama dalam proses pengirimannya dan berbayar.

Beberapa peneliti telah menggunakan Arduino Uno dan Arduino Mega untuk keamanan rumah (Dewy, 2018; Saptohadi et al., 2018; Wadhwani et al., 2018; Wijaya et al., 2017). Implementasi Internet of Things (IoT) untuk keamanan rumah ini berfungsi jika pemilik terkoneksi dengan internet atau bluetooth serta dapat mengontrol atau memonitoring rumah. Password atau perintah keamanan ini akan di kirimkan melalui SMS atau aplikasi yang telah di buat oleh peneliti dan hanya bisa digunakan pada saat itu. Pada penilitian yang telah di lakukan tersebut, tidak dijelaskan algoritma apa yang digunakan.

Berdasarkan uraian di atas, penelitian ini mengembangkan keamanan sistem login One Time Password dengan menggunakan Algoritma SHA-512 sebagai pembangkit kode OTP pada aplikasi penagihan hutang di PT. XHT. Keamanan sistem login yang penting dan utama untuk mengamankan account user agar dapat meng-auntentikasi apakah user yang menggunakan di aplikasi tersebut adalah benar - benar diri nya. Kode OTP akan dikirimkan 
melalui aplikasi android sehingga dapat menjaga keamanan account user dari user lain yang tidak berkepentingan.

\section{METODE}

Metode yang digunakan untuk membuat atau mengembangkan sistem ini adalah metode Waterfall Development. Pemilihan metode pengembangan sistem berdasarkan kesesuaian model untuk dipakai, dalam metode waterfall setiap tahapan-tahapan saling memiliki keterkaitan dan pengaruh (lihat gambar 1). Metode waterfall dimulai dari tahap Planning, Analysis, Design, Implementation, Testing, Maintenance (Pressman, 2003).

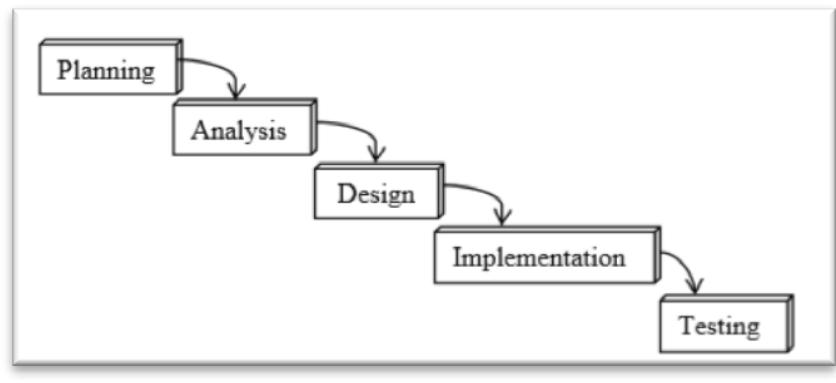

Gambar 1. Metode Waterfall

Tahapan Planning atau rencana, digunakan untuk pendefinisian tujuan, melakukan uji kelayakan teknis yang berupa ketersediaan hardware dan software, uji kelayakan operasional yang dimaksud untuk menguji kemampuan user yang akan bekerja dalam mengimplementasikan aplikasi, uji kelayakan organisasi untuk menilai kesiapan perusahaan untuk mengembangkan sistem yang akan diterapkan. Tahapan Analysis atau analisa ini dilakukan untuk menganalisis kebutuhan-kebutuhan yang diperlukan untuk membangun metode One Time Password (OTP) pada sistem penagihan hutang di PT. XHT yang didapatkan dari data kualitatif dan data kuantitatif. Data kualitatif di peroleh dari ahli media dan ahli materi berupa saran dan masukan dalam pengembangan aplikasi. Data kuantitatif di peroleh dari ahli media dan ahli materi berupa penilaian kualitas aplikasi. Nilai parameter ini memiliki rentang untuk mengetahui kelayakan pada suatu sistem. Rentang nilai dapat di lihat pada tabel 1. Tahapan Design atau model ini dilakukan untuk menerjemahkan kebutuhan yang sudah dianalisa ke sebuah perancangan perangkat lunak, tahap desain meliputi perancangan struktur data, perancangan struktur sistem, perancangan masukan dan keluaran. Tahap Implementasi atau pelaksanaan merupakan tahapan secara nyata dalam mengerjakan suatu sistem yang berguna untuk menerjemahkan desain yang telah dibuat kedalam bahasa pemrograman. Bahasa pemrograman PHP dan PostgreSql sebagai database, merupakan salah satu yang dapat dimengerti oleh komputer. Tahap akhir dilakukan uji untuk memastikan perangkat lunak dapat bekerja sesuai apa yang telah direncanakan, dan digunakan untuk menemukan kesalah dan memastikan sistem akan memberikan hasil yang diinginkan oleh user. Dalam tahap Testing atau pengujian ini, peneliti menggunakan black box untuk mengetahui apakah software yang dibuat telah sesuai dengan desainnya dan apakah masih terdapat kesalahan atau tidak, dengan dilakukan penggabungan modul-modul yang telah dibuat.

Tabel 1. Nilai Parameter Kelayakan

\begin{tabular}{ccc}
\hline No & Persentasi & Kategori \\
\hline 1. & $76 \%-100 \%$ & Sangat Layak \\
2. & $51 \%-75 \%$ & Layak \\
3. & $26 \%-50 \%$ & Cukup
\end{tabular}


4.

$0 \%-25 \%$

Kurang Layak

\section{HASIL DAN PEMBAHASAN}

\section{Hasil}

Penelitian ini menghasilkan tampilan form implementasi One Time Password (OTP) untuk keamanan login berbasis web pada aplikasi penagihan hutang di PT. XHT dengan menggunakan metode Waterfall. Adapun langkah - langkah dalam pengembangan dan pelaksanaan metode ini sebanyak 5 langkah yaitu: Planning, Analysis, Design, Implementation, Testing, Maintenance.

1. Tampilan Login User

Login User adalah tampilan pertama kali saat aplikasi di jalankan. Pada tampilan ini terdapat dua buah textarea yang berguna setelah memasukkan username dan password untuk user. Terdapat satu buah tombol button yang berfungsi untuk login (lihat gambar 2).

\begin{tabular}{|l|}
\hline User \\
Masukkan Nama \\
Password \\
Masukkan Password \\
\hline Login
\end{tabular}

2. Tampilan Input Kode OTP

Gambar 2. Tampilan Login User

Input Kode OTP adalah tampilan setelah user berhasil login. Pada tampilan ini terdapat satu buah text area yang berguna setelah memasukkan kode OTP yang di kirimkan melalui aplikasi android. Di sini juga terdapat timer untuk menghitung batas waktu penginputan kode OTP. Jika user salah menginput kode, maka akan di minta untuk menginput ulang kembali. Terdapat satu buah tombol button send yang berfungsi untuk mengirim kode OTP, seperti yang terlihat pada gambar 3 .
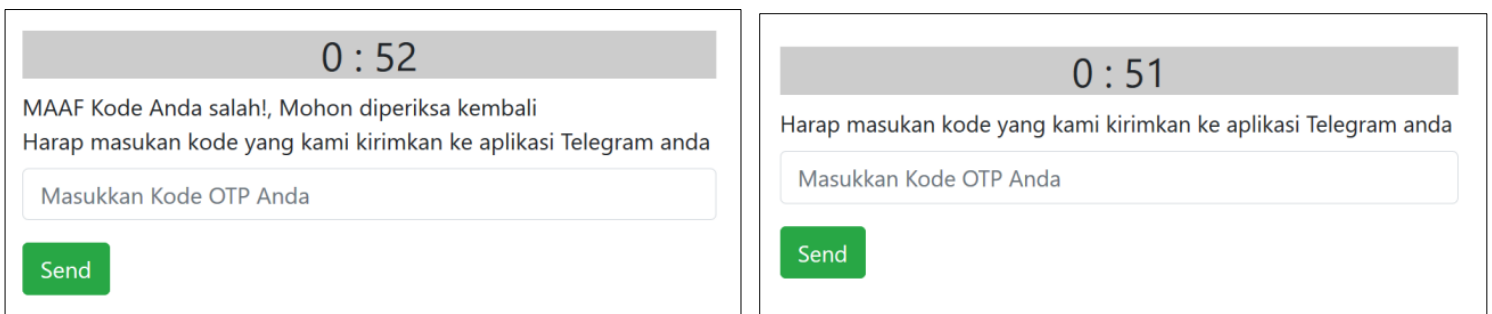

Gambar 3. Tampilan Input Kode OTP

3. Tampilan Kode OTP Pada Aplikasi Android

Kode OTP Pada Aplikasi Android adalah tampilan yang ada pada aplikasi android user untuk menerima kode OTP. Aplikasi ini hanya berfungsi mengetahui kode OTP masing - masing user (lihat gambar 4). 


\section{Tampilan Time Out Kode OTP}

Time Out Kode OTP adalah tampilan jika user terlalu lama memasukkan kode OTP. Pada tampilan ini akan muncul pop up yang memberi info kepada user bahwa waktu penginputan telah habis. Terdapat satu buah tombol button seperti pada gambar 5.

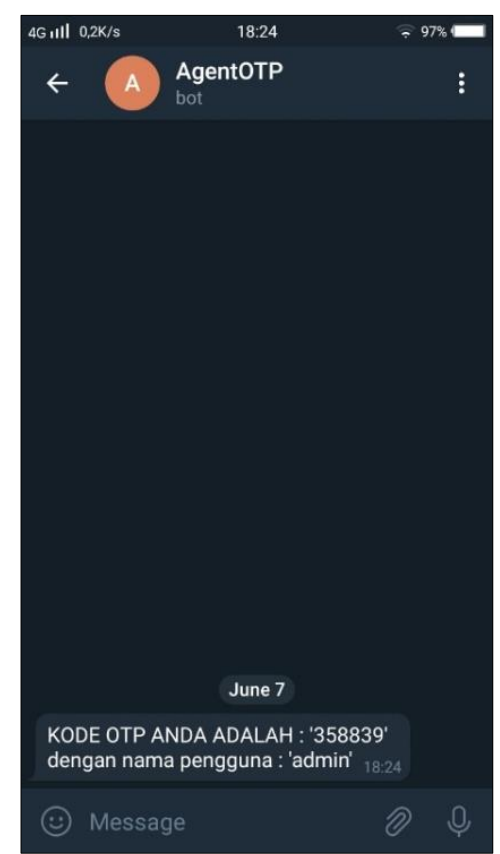

Gambar 4. Tampilan Kode OTP Aplikasi Android

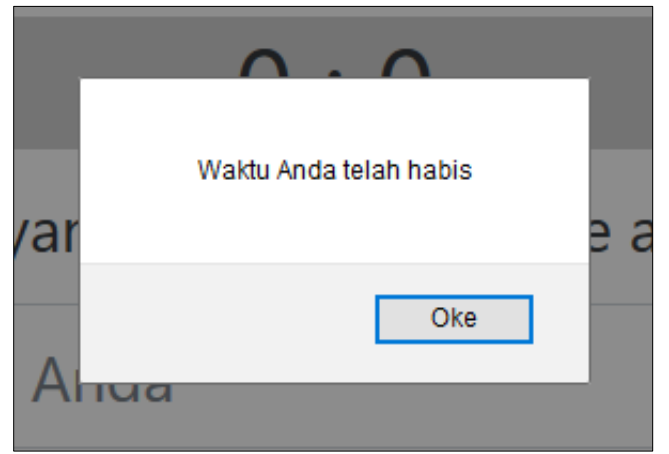

Gambar 5. Tampilan Time Out Kode OTP

5. Tampilan Menu Utama

Tampilan Menu Utama adalah tampilan menu utama user setelah berhasil login dan berhasil validasi kode OTP. Di tampilan ini user dapat melihat data client yang memiliki pinjaman di PT.XHT. Terdapat satu buah tombol button yang berfungsi untuk logout. Seperti pada gambar 6. 


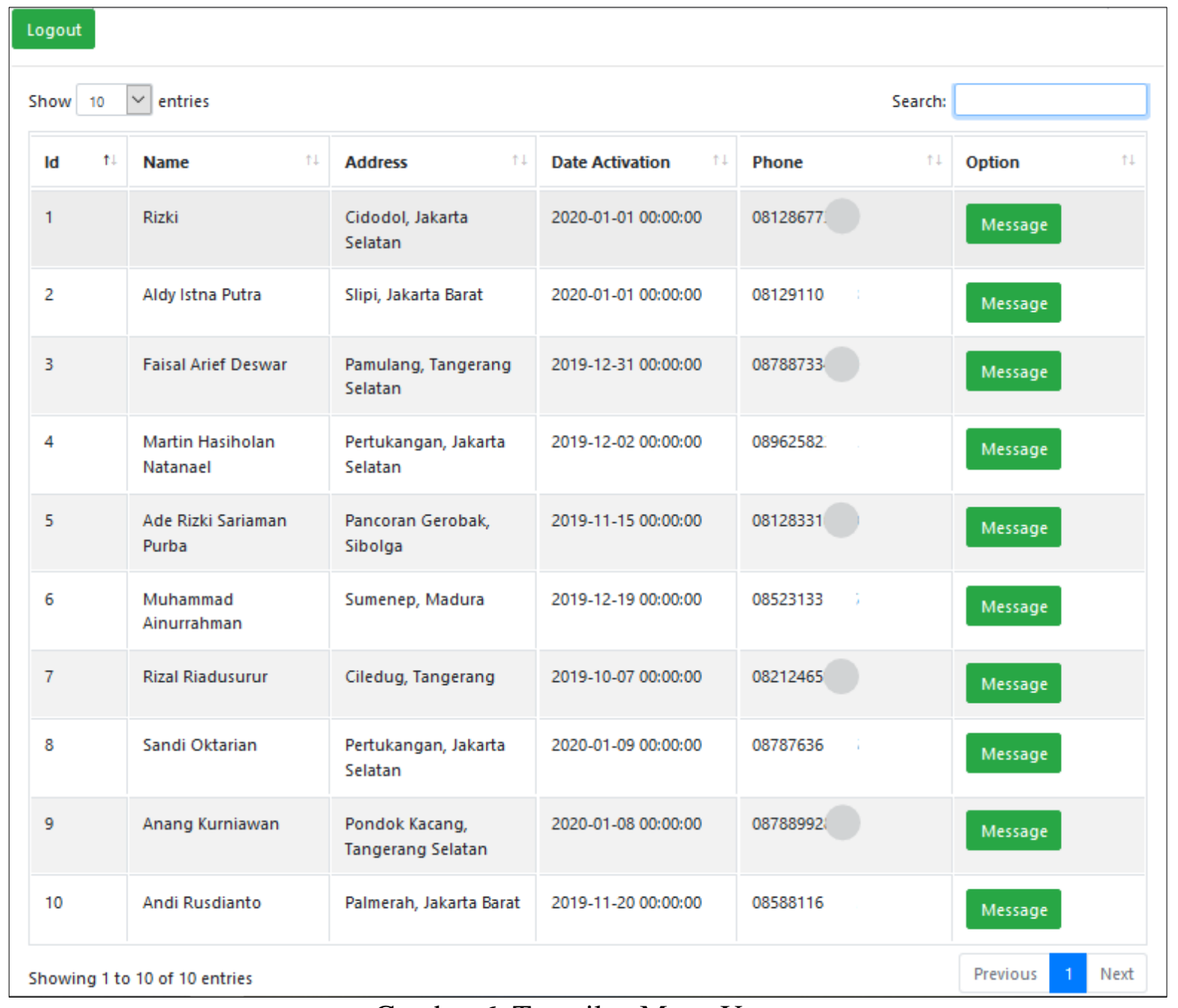

\section{Hasil Uji}

Gambar 6. Tampilan Menu Utama

Tahap ini bertujuan untuk mengetahui kelayakan pengembangan aplikasi yang di kembangkan oleh peneliti. Tahap ini berguna untuk mengetahui kesalahan yang ada pada sistem dan memperbaikinya. Pengujian di lakukan oleh peneliti sebelum merealisasikan nya ke perusahaan. Penelitian melalukan beberapa pengecekan fungsi button pada sistem yang terkoneksi pada database dan dapat di lihat pada tabel 2-4.

1. Black box login user

Black box login userberguna untuk menjelaskan button yang berfungsi di tampilan layar form login user, seperti yang terlihat pada tabel 2.

Tabel 2. Black Box Form Login User

Button Hasil uji yang diharapkan Hasil

a) Salah satu username dan password tidak di isi, akan di minta login kembali.

b) Username dan password tidak sesuai dengan isi di database, akan di minta login

Login kembali.

c) Username dan password sesuai dengan isi di database, akan masuk ke form input kode OTP. 
Keterangan :

Jika username atau password tidak di isi dan buttonlogin di klik, maka akan di minta untuk inputkembali.Jika username dan password tidak ada di dalam databasedan button logindi klik, maka akan di minta untuk input kembali.

Jika username dan passwordyang di input ada di dalam database dan button logindi klik, maka akan masuk ke dalam tampilan form input kode OTP.

\section{Black box input kode OTP}

Black box input kode otp berguna untuk menjelaskan button yang berfungi di tampilan form input kode OTP (lihat tabel 3).

Tabel 3. Black Box Form Input Kode OTP

\begin{tabular}{cccc}
\hline Button & \multicolumn{1}{c}{ Hasil uji yang di harapkan } & Hasil \\
\hline \multirow{2}{*}{ Send } & a) & $\begin{array}{l}\text { Kode OTP yang di input tidak sesuai dengan sistem, } \\
\text { akan di minta input kembali. }\end{array}$ & $\checkmark$ \\
& b) $\begin{array}{l}\text { Kode OTP yan di input sesuai dengann sistem, akan } \\
\text { masuk ke form tampilan menu utama. } \\
\text { Batas waktu input kode telah habis, akan di minta login } \\
\text { kembali. }\end{array}$ & $\checkmark$ \\
\hline
\end{tabular}

\section{Keterangan :}

Jika kode OTP yang di input tidak ada di dalam database dan button send di klik, maka akan di minta kembali untuk menginput kode OTP.

Jika kode OTP yang di input ada di dalam database dan button send di klik, maka akan masuk ke dalam tampilan menu utama.

Jika user terlalu lama menginput kode OTP sesui dengan batas waktu yang di tentukan dan button oke di klik, maka akan di minta untuk login kembali untuk mendapatkan kode OTP yang baru.

\section{Black box id user}

Black box id user berguna untuk mengetahui delay atau jedak waktu pengiriman kode otp ke aplikasi android setelah user berhasil melakukan login (lihat tabel 4).

Tabel 4. Black Box Id User

\begin{tabular}{ccccc}
\hline ID & Percobaan & Hasil uji yang di harapkan & Delay & Hasil \\
\hline \multirow{6}{*}{$\mathbf{6 6 4 8 0 2 5 2 9}$} & 1 & Kode terkirim & 9 detik & $\checkmark$ \\
& 2 & Kode terkirim & 7 detik & $\checkmark$ \\
& 3 & Kode terkirim & 5 detik & $\checkmark$ \\
& 5 & Kode terkirim & 8 detik & $\checkmark$ \\
\end{tabular}

Keterangan :

Pengujian pengiriman Kode OTP ke user melalui aplikasi android memiliki delay atau jeda waktu berkisar 5 detik sampai 10 detik.

Pengujian pengiriman Kode OTP ke user memiliki selisih waktu 1 detik sampai 5 detik.

\section{Hasil Ahli Media dan Ahli Materi}

Hasil uji ahli media berguna untuk mengetahui kelayakan dari ahli media yang melibatkan ahli media yang berpengalaman dibagiannya. Hasil uji ini dilakukan dengan 3 
aspek data validasi yang di dapat berupa tampilan media, kegunaan, dan bahasa pemograman. Persentase kelayakan yang di dapat adalah $82 \%$ dan dapat disimpulkan sangat layak, seperti yang terlihat pada tabel 5. Sementara itu, hasil uji ahli materi berguna untuk mengetahui kelayakan dari ahli materi yang melibatkan ahli media yang berpengalaman dibagiannya. Hasil uji ini dilakukan dengan 3 aspek data validasi yang di dapat berupa desain, isi, dan pembelajaran. Persentase kelayakan yang di dapat adalah $75 \%$ dan dapat disimpulkan layak, seperti yang terlihat pada tabel 6 .

Tabel 5. Persentase Ahli Media

\begin{tabular}{llcc}
\hline No & \multicolumn{1}{c}{ Aspek } & Persentase & Kategori \\
\hline 1. & Tampilan Media & $80 \%$ & Sangat Layak \\
2. & Kegunaan & $85 \%$ & Sangat Layak \\
3. & Bahasa Pemograman & $80 \%$ & Sangat Layak \\
& Rata - Rata & $\mathbf{8 2 \%}$ & Sangat Layak \\
\hline
\end{tabular}

Tabel 6. Persentase Ahli Materi

\begin{tabular}{llcc}
\hline No & Aspek & Persentase & Kategori \\
\hline 1. & Desain & $75 \%$ & Layak \\
2. & Isi & $78 \%$ & Layak \\
3. & Pembelajaran & $72 \%$ & Layak \\
& Rata - Rata & $\mathbf{7 5 \%}$ & Layak \\
\hline
\end{tabular}

\section{Pembahasan}

Berdasakan dari hasil di atas, pengimplementasi One Time Password (OTP) pada sitem login di aplikasi penagihan hutang berbasis web berjalan sangat baik dengan menggunakan bahasa pemograman PHP. Dalam pengembangan sistem ini peneliti menerapkan metode Waterfall Development di mana memiliki tahapan - tahapan, diantaranya ; Planning, Analysis, Design, Implemenstation, dan Testing. Tahap - tahap ini berguna untuk menentukan apa saja yang di butuhkan dalam mengembangkan sistem dengan cara observasi langsung ke perusahaan. One Time Password sistem keamanan login untuk account user di aplikasi ini, berhasil terkirim melalui aplikasi android dan dapat digunakan satu kali saat user tersebut melakukan login. Namun proses penginputan juga mempunyai batas waktu yang berguna sebagai validasi oleh yang dilakukan oleh sistem. Kelayakan sistem keamanan account diuji menggunakan blackbox dan validasi yang melibatkan beberapa pihak. Pihak yang terlibat dalam pengujian ini adalah ahli media dan ahli materi.

Validasi ahli media terdiri dari tiga aspek, yaitu: Tampilan Media, Kegunaan dan Bahasa Pemograman. Berdasarkan hasil penilaian pada aspek tampilan media pengembangan keamanan login berbasis web dengan pernyataan kesesuaian tata letak dan penggunaan jenis font, kejelasan warna teks dan button dengan background didapatkan skor persentase sebesar 80\% dengan kategori Sangat Layak. Sedangkan aspek kegunaan dengan pernyataan kemudahan pengoperasian aplikasi, kejelasan dalam menggunakan aplikasi mendapatkan skor persentase sebesar $85 \%$ dan dikategorikan Sangat Layak. Sedangkan aspek bahasa pemograman dengan penamaan variabel, function dan alur proses algoritma SHA-512 mendapatkan skor persentase sebesar $80 \%$ dan dikategorikan Sangat Layak. Dari hasil persentase ketiga aspek itu di dapat sebuah nilai rerata persentase sebesar 82\%. Angka ini dapat di nyatakan dalam kategori Sangat Layak jika diambil berdasarkan dari tabel 1. Namun seiring kebutuhan perusahaan aplikasi ini dapat terus di kembangkan walaupun hasil yang di dapat sangat memuaskan dalam pengembangan One Time Password (OTP) pada aplikasi ini. 
Saran dan masukan dari ahli media sangat di butuhkan dalam melakukan perbaikan dalam pengembangan.

Validasi ahli materi terdiri dari tiga aspek, yaitu ; Desain, Isi dan Pembelajaran. Berdasarkan hasil penilaian terhadap aspek desain isi dengan pernyatan kejelasan tujuan, isi, dan penggunaan aplikasi didapatkan skor persentase sebesar $75 \%$ dengan kategori Layak. Pada aspek isi dengan pernyataan kualitas isi, cakupan isi, serta kedalaman isi didapatkan skor persentase sebesar $78 \%$ dengan kategori Layak. Sedangkan aspek pembelajaran penyampaian modul, kemudahan memahami modul dalam proses pengerjaan dengan mendapatkan skor persentase sebesar 72\% dan dikategorikan Layak. Dari hasil persentase ketiga aspek itu di dapat sebuah nilai rerata persentase sebesar 75\%. Angka ini dapat di nyatakan dalam kategori Layak jika di dambil berdasarkan dari tabel 1. Namun seiring kebutuhan perusahaan aplikasi ini dapat terus di kembangkan walaupun hasil yang di dapat sangat memuaskan dalam pengembangan One Time Password (OTP) pada aplikasi ini. Saran dan masukan dari ahli materi sangat di butuhkan dalam melakukan perbaikan dalam pengembangan.

Berdasarkan penilaian validasi oleh ahli media ahli materi dan dapat di ambil garis besar bahwa pengembangan One Time Password (OTP) aplikasi ini layak di gunakan. Keamanan account user dapat terjaga dengan baik karena kode angka hanya dapat di gunakan sekali saat user melakukan login dan sistem dapat meng - otentikasi bahwa yang menggunakan kode angka tersebut benar - benar user itu sendiri. Otentikasi dapat menghindari dari penyalahan gunaan account dari orang yang tidak berkepentingan.

\section{SIMPULAN}

Berdasarkan penelitian dan pembahasan, implementasi One Time Password (OTP) menggunakan Algoritma SHA-512 pada aplikasi penagihan hutang PT. XHT ini menggunakan metode Waterfall Development. Hasil uji dari blackbox menunjukkan bahwa pengembangan sistem keamanan login ini berfungsi dengan baik dan sesuai dengan hasil yang di harapkan.Hasil kelayakan media dari ahli media mendapat total persentase sebesar $82 \%$ dengan kategori sangat layak dan hasil kelayakan materi dari ahli materi mendapat total persentase sebesar $75 \%$ dengan kategori layak.

\section{REFERENSI}

Adilah, S., Mangkudjaja, R. R., \& Paryasto, M. W. (2017). Implementasi Kriptosystem menggunakan metode Algoritma ECC dengan Fungsi Hash SHA-256 pada sistem ticketing online Implementation of Crypthosystem using Method Algorithm ECC with Function of Hash SHA- 256 in online ticketing system. E-Proceeding of Engineering (pp.4138-4146). Indonesia: Telkom University press.

Al Azam, M. N. (2016). Otentikasi Sistem Dengan Menggunakan One Time Password Memanfaatkan Smartphone Android. Link, 24(1), 7-10.

Dewy, N. A. (2018). Kontrol Akses Pintu Rumah Menerapkan Konsep OTP (One Time Password) Untuk Meningkatkan Keamanan Dengan Implementasi IoT (Internet Of Things ). JATI (Jurnal Mahasiswa Teknik Informatika), 2(1), 467-473.

Khairina, D. M. (2011). Analisis Keamanan Sistem Login. Jurnal Informatika Mulawarman, $6(2), 64-67$.

Kinarwanto, B. (2016). Faktor-Faktor Pemanfaatan Teknologi Informasi dan Pengaruhnya Terhadap Kinerja Individual (Studi pada PDAM Kota Malang). Jurnal Ilmiah Mahasiswa Fakultas Ekonomi Dan Bisnis, 1(2), 1-19.

Kurniawan, M. B., \& Fatimah, T. (2018). Aplikasi Nilai Online Menggunakan One Time Password Dengan Algoritma Sha 512 Berbasis Web Pada Smp Pgri 336. Skanika, 1(1), 411-416. 
Mulya, M. (2009). Penggunaan Algoritma SHA-512 Untuk Menjamin Integritas dan Keotentikan Pesan Pada Intrainet. Konferensi Nasional Sistem Dan Informatika (pp.107-111). Indonesia: STMIK STIKOM Bali press

Naufal, M., \& Purwanto. (2018). Implementasi Keamanan Login Dengan Metode One Time Password ( Otp ) Menggunakan Fungsi Hash Algoritma Sha-512. Skanika, 1(1), 335339.

Pressman, R. (2003). Rekayasa Perangkat Lunak Pendekatan Praktis. 2nd, Andi. Yogyakarta. Indonesia.

Sakti, D. V. S. Y., Agani, N., \& Hardjianto, M. (2016). Pengamanan Sistem Menggunakan One Time Password Dengan Pembangkit Password Hash SHA-256 dan Pseudo Random Number Generator (PRNG) Linear Congruential Generator (LCG) di Perangkat Berbasis Android. Budi Luhur Information Technology, 13(1), 1-10.

Saptohadi, W., Ritzkal, \& Prakosa, B. A. (2018). Implementasi QR Ccode Dinamic Pada Sistem One-Time Password (OTP) Sebagai Key Penggerak Solenoid Berbantuan Arduino Mega 2560. Seminar Nasional Teknologi Informasi (pp.782-788). Indonesia: Universitas Ibn Khaldun press

Sugiyatno, \& Atika, P. D. (2018). Digital Signature Dengan Algoritma Sha-1 Dan Rsa Sebagai Autentikasi. Jurnal Cendikia, 16(2), 74-83.

Wadhwani, S., Singh, U., Singh, P., \& Dwivedi, S. (2018). Smart Home Automation and Security System using Arduino and IOT. International Research Journal of Engineering and Technology (IRJET), 5(2), 1357-1359.

Wijaya, C. H., Hendrawan, A. H., Pramuko, A. E. K., \& Goeritno, A. (2017). Implementasi Sistem One-Time Password (OTP) Sebagai Key Penggerak Kunci Pintu berbantuan Arduino Uno. Seminar Nasional Inovasi Dan Aplikasi Teknologi Di Industri (pp.1-7). Indonesia: ITN Malang press.

Yahya, N. I., \& Amini, S. (2018). Pengimplementasia One Time Password dan Notifikasi Email menggunakan Fungsi Hash SHA-512 Berbasis Web Pada SMK Cyber Media. Skanika, 1(2), 745-750. 